\title{
PADRE DIOGO ANTÔNIO FEIJÓ: as contro- vérsias de um sacerdote regalista e anticelibatário
}

\author{
Father Diogo Antônio Feijó: controversies \\ of a regalist and anti-celibatary priest
}

\section{Dilermando Ramos Vieira}

Mestre em Mariologia pela Pontifícia Faculdade “Marianum”, Doutor em História Eclesiástica pela Pontifícia Universidade Gregoriana, ambas em Roma, professor de História da Igreja Moderna e Contemporânea também na Pontifícia Faculdade "Marianum", Roma - Itália, e-mail: dilermando.ramos@gmail.com

\section{Resumo}

Padre Diogo Antônio Feijó foi um destacado político, cujas propostas cívicas e religiosas ainda hoje suscitam curiosidade. Feijó, pelo que representou e pelas posturas que assumiu ante a religião da qual era ministro, só pode ser compreendido dentro das circunstâncias em que viveu, as quais ele viria a transcender, tanto pelo radicalismo com que defendeu seus pontos de vista, quanto pela pertinácia com que foi combatido. Deve-se ter presente que, na política então dominante no Brasil, o "regalismo" era uma das notas características. Feijó foi um apologista convicto dessa posição, e o fato de ser padre jamais impediu que colocasse os interesses da Igreja em segundo plano na sua vida. Por outro lado, ser filho bastardo de um clérigo sempre o deprimiu, e isso, segundo alguns estudiosos, teria provocado nele verdadeira aversão pelo celibato clerical, por percebê-lo como causa de sua dor.

Palavras-chave: História da Igreja. Século XIX. Feijó. Regalismo. 


\section{Abstract}

The father Diogo Antônio Feijó was a great politician, whose civic and religious proposals still raises curiosity nowadays. Feijo, because of his importance and because of the statements he assumed before the religion of which he was a minister, can be understood only in the circumstances he lived, which he came do overcome, as by the radicalism with which he defended his point of view, as by the strength with which he was defeated. It is needed to be aware that, in the dominant politics of Brazil at that time, the regalism was one of the main point. Feijo was an convinced apologist of that position, and the fact of being a priest never was an obstacle to put the Church's interest in a second position. On an other hand, being a bastard son of a clergyman always made him depressed, and this, confirmed by some thinkers, resulted in his real aversion to the clerical celibacy, as it was seen as the motive of his pain.

Keywords: Church History. XIX century. Feijó. Regalism.

Três sacerdotes brasileiros marcaram época na primeira metade do século XIX: Pe. José Maurício Nunes Garcia, Frei Joaquim do Amor Divino Rabelo (Frei Caneca) e Pe. Diogo Antônio Feijó. O primeiro foi um gênio da música lírica; o segundo, um destemido líder revolucionário da Confederação do Equador; e o último, um destacado político, cujas propostas cívicas e religiosas ainda hoje suscitam curiosidade. Feijó, pelo que representou, e pelas posturas que assumiu ante a religião da qual era ministro, só pode ser compreendido dentro das circunstâncias em que viveu, as quais ele viria a transcender, tanto pelo radicalismo com que defendeu seus pontos de vista, quanto pela pertinácia com que foi combatido.

Nesse sentido, deve-se ter presente que, na política então dominante no Brasil, o regalismo era uma das notas características. Esse sistema - regalismo - se baseava na doutrina que o chefe de Estado estava investido do "direito" próprio de intervir em vários assuntos religiosos. Os precedentes na Europa eram numerosos, a exemplo do galicanismo francês, do josefinismo austríaco, do febronianismo alemão e do pombalismo português. No Brasil, o Império 
deu continuidade ao pombalismo, razão pela qual, ao outorgar em 1824 a primeira Constituição do Brasil, Dom Pedro I estabeleceu em seu artigo quinto o seguinte princípio: "A Igreja Católica Apostólica e Romana continuará a ser a religião do Império" (BRASIL, 1863, p. 5).

Explicando melhor: não bastasse a total ausência de diálogo prévio com a Santa Sé, por meio do verbo "continuará" o Estado impôs por sua própria iniciativa uma tutela sobre a instituição eclesiástica, em nome da legitimação de um fato e de um "direito" preexistentes. E não terminou aí: entre 1824 e 1829 , a legislação tudo fez para "enquadrar" a vida religiosa e clerical segundo as conveniências da Coroa. Isso se manifestou em diversas ocasiões: no ano de 1827 o Governo declarou que o padroado era "um direito próprio do príncipe civil" e não uma concessão do Sumo Pontífice, ao que se seguiu um conjunto de medidas em que os referidos "direitos" imperiais sempre prevaleciam. Assim, a validade das bulas pontifícias ficou subordinada ao querer do Trono, a economia das ordens religiosas sofreu intervenção, e algumas delas acabaram inclusive sendo suprimidas. As medidas mais drásticas contra os regulares começaram a se concretizar em 1824, com a supressão dos Agostinianos da Bahia, seguida da dos Carmelitas descalços e dos Capuchinhos em 1828 (PIRES, 1946, p. 367-371).

Feijó foi um apologista convicto dessas atitudes, e o fato de ser padre jamais impediu que colocasse os interesses da Igreja em segundo plano na sua vida (PIRES, 1946, p. 387). Por outro lado, ser filho bastardo de um clérigo sempre o deprimiu, e isso, segundo alguns estudiosos, teria provocado nele verdadeira aversão pelo celibato clerical, por percebê-lo como causa de sua dor. Não demorou muito e tal sentimento extravasaria com toda sua virulência (ELLIS JÚNIOR, 1940, p. 115).

\section{A primeira fase de Feijó (1784-1821)}

Numa manhã de inverno, mais exatamente numa manhã do dia 17 de agosto de 1784, na soleira da casa do Pe. Fernando Lopes de Camargo, situada na Rua da Freira n. 11, na esquina do Beco da Santa Casa, em São Paulo, apareceu depositado um estranho volume. Os curiosos se achegaram, e quando o Pe. Fernando regressou, momentos depois, deparou-se com um grupo ruidoso ao redor de um recém-nascido, vestido com roupas bastante confortáveis. 
Demonstrando uma estranha calma, o padre recolheu o enjeitadinho, e encerrou a conversa com um parecer lacônico: "É bem-vindo à nossa morada o nosso hóspede. Quem sabe não estará aqui um vulto necessário à religião e à pátria?" (ORICO, 1930, p. 23).

O assunto, porém, como não podia deixar de ser, deu espaço a murmurações. Suspeitou-se que o menino fosse filho de Maria Gertrudes, irmã do Pe. Fernando, então viúva do português Miguel João de Feijó, que teria concedido seus favores a um parente do seu falecido marido, um certo Félix Antônio Feijó; mas isso atualmente é descartado. Hoje, a hipótese mais aceita é de que Diogo Antônio Feijó era filho da outra irmã do padre, Maria Joaquina, que tinha 23 anos e que com ele habitava. O pai, ao que tudo indica, foi o vigário de Cotia, mais tarde cônego do cabido paulistano, Manuel da Cruz Lima. Reforça a suspeita sobre Maria Joaquina o fato de ela ter tido outra filha natural 11 anos depois, Maria Justina, por quem Feijó nutriria particular afeição. Seja como for, o pequeno teve boa acolhida, sendo batizado no mesmo dia em que foi encontrado. Pe. Fernando, seu tio, foi o padrinho (ELLIS JÚNIOR, 1940, p. 37), mas conservou no batistério a lacuna: "pais ignorados". ${ }^{1}$

O menino passou os três primeiros anos da sua infância na abundância de uma fazenda de Cotia (TALASSI, 1949, p. 31). De volta à capital, cresceu cercado de relativa comodidade na casa do tio, tomando parte da sua intimidade. As coisas iam nesse ritmo quando, em 1800, já adolescente, mudou-se para a Vila de São Carlos (atual Campinas), onde passou a estudar retórica com o professor régio Estanislau José de Oliveira (conhecido como "Gica retórica"), e a influência desse mestre sobre sua personalidade, ao que tudo indica, foi decisiva. Estanislau era um português de ideias liberais pombalinas, que teve de fugir para o Brasil quando a rainha, Dona Maria I, mudou o curso da política lusitana. No novo ambiente, esse professor continuou fiel às ideias de outrora, transmitindoas com ardor a Feijó e ao restante do grupo de nove alunos para quem ensinava. Foi também nesse período que o jovem Diogo começou a dar-se conta dos limites impostos pela condição de filho natural que o marcava. Considerando tal situação,

1 Segundo livro de registros da Sé paulista, disponível no Arquivo da Cúria Arquidiocesana de São Paulo, o batismo de Feijó foi anotado assim: “Aos 17/08/1784 nesta Sé, batizei e pus os santos óleos a Diogo, filho de pais ignorados, exposto em casa do Rev.mo Pe. Fernando Lopes de Camargo; o mesmo foi padrinho, e Maria de Gertrudes Camargo, viúva, e todos desta freguesia, do que para contar, fiz este assento, que assino. O Coadjutor José Joaquim da Silva" (SOUZA, 1988, p. 23).

Rev. Pistis Prax., Teol. Pastor., Curitiba, v. 2, n. 1, p. 193-210, jan./jun. 2010 
Alfred Ellis Júnior coloca em dúvida sua vocação sacerdotal. Para ele, Feijó tornou-se padre por falta de opção, uma vez que o presbiterato seguramente foi a única forma que ele teria encontrado para vencer os preconceitos de então e ascender socialmente (ELLIS JÚNIOR, 1940, p. 51).

Certo é que, após completar o curso de humanidades, Diogo Antônio Feijó ingressou no improvisado "seminário" de Campinas (PIRES, 1946, p. 367-383), no qual, por força das circunstâncias, se tornou um autodidata. Em dezembro de 1808 foi ordenado diácono na capela particular do palácio episcopal de São Paulo, por Dom Mateus de Abreu Pereira (1742-1824), e no ano seguinte se tornaria presbítero (TALASSI, 1949, p. 34).

Como sacerdote, exerceu um primeiro ofício na cúria, mas pouco depois foi mandado para Guaratinguetá, em seguida para Parnaíba e, por fim, para Campinas. De lá se mudou ainda para Itu e, após uma experiência com escravos na agricultura, montou seu próprio colégio interno, onde reservou para si as cadeiras de filosofia, lógica e moral. Religioso de hábitos sóbrios, idoneidade moral inatacável, enérgico, de caráter dos mais firmes, Diogo paulatinamente ganhou notoriedade, sobretudo a partir do momento em que passou a defender abertamente a separação do Brasil de Portugal (ELLIS JÚNIOR, 1940, p. 56). Preanunciava-se aí uma nova fase de sua vida: a política. Porém, desse momento em diante, começaria igualmente a pôr de lado seus deveres sacerdotais, o que incluiu até o abandono do repouso dominical em determinadas ocasiões (KIDDER, 1972, p. 247).

\section{Ascensão e queda de Feijó (1821-1843)}

Em 1821, Diogo Antônio Feijó fez parte da delegação brasileira eleita para participar da reunião das "Cortes Gerais e Extraordinárias da Nação Portuguesa" em Lisboa; mas em fevereiro do ano seguinte, assim que assomou ao prédio do parlamento, ele se deu conta de que os brasileiros eram uma minoria hostilizada, com os reinóis desejando a todo custo recolonizar o Brasil. O clima era de afronta aberta, e o empedernido colonialista Manuel Borges Carneiro (1774-1833) vociferava: "O Brasil precisa é de um cão de fila para pô-lo na ordem" (SARAIVA, 1993, p. 283). Ele enfrentou com audácia a situação e, ao proferir seu primeiro e incisivo discurso, adotou um tom provocatório: "Nenhum povo tem o direito de impor a outro suas constituições. 
[...] Proponho o reconhecimento da independência das antigas capitanias até a publicação de lei constitucional..." (ORICO, 1930, p. 37).

Com o transcorrer das sessões nos meses seguintes, o ambiente tornouse sempre mais tenso, piorando de vez quando os "alfacinhas" (nome popular dado aos lisboetas) ouviram boatos vindos da América, comunicando que Dom Pedro proclamara a independência brasileira aos 7 de setembro de 1822. Poucas semanas depois, a população local levantou-se em fúria contra os "traidores ultramarinos"; mas a delegação brasileira já havia abandonado as Cortes e retornado ao Brasil no dia 06 de outubro (ORICO, 1930, p. 38).

Feijó desembarcou em Recife no dia 21 de dezembro de 1822, e após breve estadia em Pernambuco seguiu para o Rio de Janeiro, aonde chegou em 20 de março. Muita coisa mudara no seu comportamento: no contato com o ambiente político ele reforçara certas convicções, e estava bem mais liberal do que quando partira. Em breve levaria para o campo religioso tais convicções (TALASSI, 1949, p. 31).

\section{A eclosão da controvérsia em torno do celibato clerical}

Em 3 de março de 1826, Pe. Feijó tomou posse na primeira legislatura da Câmara dos Deputados, como suplente de José Feliciano Fernandes Pinheiro, o visconde de São Leopoldo (1774-1847), escolhido para senador naquele ano. Ao chegar à capital federal para exercer o mandato, trazia pronto um projeto inspirado na Constituição Civil do Clero, imposta pela revolução francesa em 1790, que pretendia aplicar ao Catolicismo no Brasil. Ele o apresentou ao padre Romualdo Antônio de Seixas Barroso (1787-1860), mas aquele o rejeitou categórico (SEIXAS, 1861, p. 43).

Sem se desanimar diante da negativa, o clérigo paulista tentou efetivar sua proposta assim que foi eleito para as comissões de Instrução Pública e Negócios Eclesiásticos da Câmara Federal. Encontrou o pretexto que desejava no dia 10 de outubro de 1827, quando o deputado e médico baiano Antônio Ferreira França, o "Francinha" (1771-1848), elaborou proposta de lei abolindo o celibato clerical no Brasil. Sem esperar o parecer dos colegas da Comissão Eclesiástica, Feijó apresentou um voto separado, no qual, além de apoiar a iniciativa, atribuía ao Estado a competência de legislar livremente sobre a disciplina interna da Igreja. Em defesa da mudança, ele opinava que o celibato 
era injusto, um "despotismo horroroso", estando em vigor porque a Igreja alterara a disciplina dos séculos apostólicos. Sem considerar a possibilidade de uma regeneração dos costumes do clero, servia-se dos exemplos de prevaricação de que estava a par justamente para legitimar a mancebia: "São fraquezas da humanidade, mas convém por isso mesmo não advogar contra ela, porque todos somos homens...".2

Pe. Romualdo Seixas - que seria sagrado bispo no ano seguinte estava no parlamento no momento em que a proposta foi apresentada e, percebendo que se tratava de uma questão pessoal do autor, retrucou: "Deixemonos de casamentos de padres, e vamos tratar de coisas que possam ser úteis e profícuas à prosperidade da pátria". Feijó, porém, insistiu, e propôs que o seu voto fosse impresso e a opinião pública, sondada (ANAIS... 1876, p. 120).

Atenderam-no, mas o efeito foi exatamente o contrário do que imaginava: Dom Romualdo soube explorar com êxito as fraquezas do autor e do seu documento, e entre uma ironia cáustica e outra, perguntava se quando Feijó afirmara que "afinal, somos homens", não estaria advogando em causa própria. A partir daí, usando de uma dialética persuasiva e inteligente, fazia aliados entre os colegas, ao tempo em que a figura do controvertido clérigo paulista ia caindo na boca do povo, e se tornando o tema preferido das rodinhas maldizentes. A parte diretamente interessada, isto é, os padres, tampouco se entusiasmou com a ideia. Em São Paulo, alguns anticelibatários até que aproveitaram para criarem um silogismo: "O casamento é melhor que a mancebia. Ora, os clérigos do Brasil usam da mancebia. Logo, é melhor que se casem"; mas tiveram de enfrentar consistente grupo opositor, que revidou: "A Igreja impõe o celibato aos que recebem ordens sacras. Ora, muitos não querem observar o celibato. Logo, não devem receber ordens sacras" (RUBERT, 1993, p. 32).

Feijó saiu em campo para defender seu voto separado, e fê-lo com tanta paixão que cogitou até mesmo a possibilidade de um cisma, se fosse necessário para salvar a "prioridade nacional". Como, no entanto, a resistência às suas idéias não diminuísse, no ano seguinte - 1828 - ele escreveu outra obra de nome "Demonstração da necessidade da abolição do celibato clerical pela Assembléia Geral do Brasil e da sua verdadeira e legítima competência nesta

2 ASV, "Voto do Deputado Diogo Antônio Feijó como membro da Comissão Eclesiástica sobre a Indicação do Sr. Deputado Ferreira França, em que propõe que o clero do Brasil seja casado", In: Nunciatura Apostólica no Brasil, fasc. 10, caixa 3, doc. n. 4, fl. 9-15b. 
matéria", insistindo em cada ponto que havia dito. Teve, porém, de enfrentar seu mais temível opositor: o Pe. Luiz Gonçalves dos Santos (1767-1844). Também conhecido como "Padre Perereca", devido à sua particular compleição física, esse sacerdote juntou-se ao Visconde de Cairu, e ao carmelita frei Perez, e abriu um combate sem tréguas às ideias contidas no voto separado. Feijó perdeu: a Comissão Eclesiástica, na pessoa de José de Souza Melo, rejeitou de forma decidida tanto o projeto de "Francinha" quanto ao seu parecer, por julgálos ofensivos à doutrina e à Constituição.

O irrequieto padre não desistira da sua luta, mas a crise interna com que se debatia o Primeiro Império não permitiu que se abordasse de novo questões do gênero. Entretanto, após a abdicação de Dom Pedro I, ele teve nova chance de retomar sua peleja, depois que a Regência o nomeou como titular da pasta da Justiça em 4 de julho de 1831. Em seguida, além de reascender as polêmicas anteriores, ele acrescentou questões novas. A bem da verdade, a celeuma tinha sido reaberta antes mesmo que o padre tomasse posse, uma vez que, nos dias 17 de maio e 11 de junho precedentes, Feijó, acompanhados pelo Pe. Antônio Maria de Moura e outros regalistas, articulou três polêmicos projetos que de nenhum modo poderiam ser - e de fato não foram - aceitos pela Santa Sé: o da "caixa eclesiástica", o do "presbitério" e um último sobre o matrimônio. ${ }^{3}$

O terceiro projeto era o mais controvertido de todos, porque propunha a abolição do celibato clerical como impedimento para contrair núpcias ou exercitar o ministério sacerdotal. Lido o parecer da comissão no plenário da câmara na sessão de 26 de julho de 1831, os debates foram retomados de forma violenta. De novo, nenhum dos três projetos teve prosseguimento, porque uma questão política mais urgente teve que ser abordada: a tutoria do príncipe herdeiro. O ministro Feijó mandara prender José Bonifácio, acusado de rebelião, e pediu autorização ao legislativo para exonerá-lo da função de tutor de Dom Pedro II. O acusado era membro da poderosa família Andrada, e seus irmãos, liderados por Martim Francisco, tudo fizeram para defendê-lo; mas, em 30 de julho de 1832, a comissão da justiça criminal condenou-o por 45 votos contra 31. Faltava ainda o parecer do senado, e ali a situação se inverteu: pela diferença de apenas um voto José Bonifácio foi mantido no cargo. Sentindo-se agredido moralmente, Feijó pediu demissão no dia 2 de agosto seguinte e regressou a São Paulo.

ASV, "Lettera di Francesco Cappacini al Incaricato d'affari della Santa Sede a Rio de Janeiro", In: Nunciatura Apostólica no Brasil, fasc. 18, caixa 4, doc. 82, fl. 233; doc. 84, fl. 265.

Rev. Pistis Prax., Teol. Pastor., Curitiba, v. 2, n. 1, p. 193-210, jan./jun. 2010 
Lá, tendo como fiel aliado o Pe. Manoel Joaquim do Amaral Gurgel, reiniciaria a luta contra o celibato, tentando convencer o bispo diocesano Dom Manuel Joaquim Gonçalves de Andrade (1775-1847) a suprimir a continência obrigatória na sua jurisdição. Feijó defendia seu projeto baseando-se, sobretudo, em dois argumentos: "Os bispos em suas dioceses podem tudo o que pode o Sumo Pontífice na Igreja Universal; e a lei do celibato não é senão disciplinar, dispensável por qualquer bispo", arguindo-se daí que o bispo de São Paulo podia e devia, naquela circunstância, "dispensar os seus padres da lei do celibato". Pego de surpresa, o Ordinário de lugar, que não era exatamente um homem de energia, esquivou-se, submetendo a questão ao Governo central. A Santa Sé, conforme consta numa carta do cardeal Tommaso Bernetti (17791852) ao seu encarregado no Brasil, teria ficado constrangida com a fraqueza de caráter do prelado de São Paulo, e o próprio Papa o repreenderia por haver dado ouvidos aos anticelibatários, em vez de cumprir seu dever, rejeitando uma proposição que feria a disciplina geral da Igreja. ${ }^{4}$

O internúncio Scipione Fabbrini, por sua vez, em 18 de fevereiro de 1834 escreveu ao ministro dos negócios estrangeiros, Conselheiro Aureliano Coutinho (1800-1855), futuro marquês de Sepetiba, pedindo explicações e providências. $\mathrm{O}$ ministro respondeu-lhe com extrema rudeza, não hesitando em sustentar que "o Governo de Sua Majestade está convencido de que o celibato dos padres constitui um ponto de disciplina que os Soberanos podem alterar à vontade, em benefício de seus súditos". Como, porém, ele não era versado no assunto, antes de submeter tal Representação ao conhecimento das Câmaras, expediu um aviso em 3 de março, pedindo com urgência a Dom Romualdo o seu parecer. O primaz não gostou nada da solicitação e na resposta que deu, no dia 14 de junho de 1834, fez questão de manifestá-lo:

É sobremaneira doloroso ter de pronunciar um juízo, ou emitir uma opinião acerca da Representação do Conselho Geral de São Paulo, [...] quando o mesmo Conselho parece querer prevenir e como intimidar os que não pensam como ele, reduzindo-os a um punhado de rudes e ignorantes, e mimoseando-os com os odiosos epítetos de superstição a mais estúpida, ou da mais refinada imoralidade (SEIXAS, 1861, p. 349, grifo do autor).

4 ASV, "Carta do Cardeal Bernetti ao Encarregado da Santa Sé no Rio de Janeiro" (28/5/ 1835), In: Nunciatura Apostólica no Brasil, fasc. 18, caixa 4, doc. 57, fl. 145. 
Ainda assim, ele anexou a explicação pedida - rejeitando completamente o controvertido projeto -, por entender que, em uma questão dessa natureza, um bispo não podia ficar mudo. $O$ parecer que deu foi levado a sério, fazendo a proposta cair. Amaral Gurgel, na desesperada tentativa de inverter o veredicto, publicou uma réplica ao parecer de Dom Romualdo, alertando para o "risco" que representava essa nova "usurpação" do clero (GURGEL, 1834, p. 3). O escrito passou quase que ignorado, e o primaz do Brasil, sem sequer citá-lo, anos mais tarde se resumiria a contar, não sem certa ironia, a reação que tiveram os "padres noivos":

Nada, porém, foi mais cômico e interessante que a cena que se passou na Câmara dos Deputados, onde também me achava, no momento de abrirse e anunciar-se a minha resposta. [...] Pe. Joaquim do Amaral Gurgel disse que já estava de casamento marcado e cobriu de injúrias o Arcebispo. [...] O projeto caiu "com grande mágoa e desespero dos noivos". (SEIXAS, 1861, p. 84).

O episódio evidenciou ainda outros dois fatos: o tratamento político que as autoridades deram ao caso e o alinhamento de parte da hierarquia eclesiástica ao status quo. Ou seja, não foi a situação moral do clero nem a observância da disciplina estabelecida pelo Concílio de Trento que provocou o desfecho, mas a conveniência: Feijó e seus pares não tiveram suficientes argumentos para contrastarem opositores mais cultos, ou cooptar o apoio da maioria. No tocante à acomodação de um segmento do clero ao regalismo, tampouco há motivo de espanto: muitos deles eram simples sacristãos que, depois de acolhidos, "progrediam" como fosse possível ao longo dos anos, até receberem a tonsura e, por fim, o diaconato e o presbiterado. E tudo isso quase sempre sem fazerem estudos ou passar em exames. Não por acaso, o inglês Richard Francis Burton, ao visitar o Brasil, afirmaria mais tarde que a hierarquia eclesiástica no país havia passado por "mudanças notáveis" em relação ao seu centro legítimo (BURTON, 1976, p. 333).

\section{A questão da vacância da diocese do Rio de Janeiro}

A mais grave crise religiosa da Regência teve início quando se fez necessário encontrar um sucessor para o prelado do Rio de Janeiro, Dom José 
Caetano da Silva Coutinho (1768-1833), falecido em 27 de janeiro de 1833. No dia 22 de março seguinte, o brigadeiro Francisco de Lima e Silva, na condição de membro da Regência Trina Permanente, por meio de um decreto cometeu a temeridade de indicar o Pe. Antônio Maria de Moura, provocando a reação imediata do Encarregado Pontifício, que no mesmo dia advertiu Honório Hermeto, ministro da Justiça e Negócios Eclesiásticos, que o fato do referido padre haver subscrito os três projetos rejeitados se constituiria numa grande dificuldade para uma eventual instituição canônica. ${ }^{5}$

Dois anos depois, também Feijó seria nomeado prelado de Mariana, mas prudentemente declinou a oferta. Pe. Antônio Moura, ao contrário, mal soube da citação do seu nome, aceitou-a de boa vontade. O que ele não contava é que a imprensa transformaria essa pretensão num clamoroso escândalo. No dia 29 de março de 1833, o jornal carioca $O$ Carijó atacaria abertamente a escolha feita, recordando que o indicado, Moura, na condição de filho ilegítimo de Paulo Fernandes Viana, segundo o estabelecido pelo Concílio de Trento, estava canonicamente impedido de se tornar bispo, sendo mais que provável que Roma rejeitasse "tal sujeito". Quatro dias depois, o satírico periódico $O$ Par de Tetas diria ferino que o novo critério para se nomear bispo tinha se tornado vestir-se à moda de "pelintra" antes que de padre, ser membro de alguma comissão defensora do casamento dos sacerdotes e embebedar bastante-se.

O jornal O Permanente Constitucional também se ocuparia do assunto, mas nenhuma publicação fez mais estrago ao sonho de Moura que o número 6 da Arca de Noé, que chegou ao público no dia 13 daquele mesmo mês de abril. $\mathrm{O}$ autor, como era próprio do estilo, fê-lo de forma anônima, mas a posteridade o identificaria: era José Bonifácio, que chegou a tanto por puro desejo de vingança. Isso porque, após a queda de Feijó, a Regência o reintegrara na função de tutor de Dom Pedro II, para pouco depois, através duma proclamação lacônica, pontuada de acusações vagas, humilhá-lo com uma demissão sumária. Conhecendo as reais limitações do indicado para o Rio, José Bonifácio viu nele a grande oportunidade de desforra contra os regentes, e assim, no artigo supracitado, explorou com crueza todas as suas mazelas. Sem medir palavras, ele deixava bem claro que a Regência e o ministro que lhe referendara o nome sabiam muito bem que "o Sr. Antônio Maria de Moura,

ASV, "Breve memória histórica anexa à nota dirigida ao Senhor Drumonnd, encarregado dos negócios do Brasil”, In: Nunciatura Apostólica no Brasil, fasc. 18, caixa 4, doc. 83, fl. 299. 
membro da comissão eclesiástica da câmara dos deputados, organizara com seus dois 'dignos' colegas os escandalosos e heterodoxos projetos", um dos quais, nada mais queria que "acabar com a religião de Cristo que todo o povo do Brasil sinceramente ama e quer, à exceção desses inovadores, heréticos e libertinos". O maçom Bonifácio, parafraseando o "Santíssimo Padre Gregório XVI", sublinharia que "a nossa Sé Romana de São Pedro, sobre quem Cristo pôs os fundamentos da Igreja, é assaltada de todas as partes, e os laços de unidade de dia em dia cada vez mais se enfraquecem e dilaceram". ${ }^{6}$

O Governo, minimizando os efeitos do artigo sensacionalista e a advertência do representante pontifício, no dia 3 de maio de 1833 enviou do Rio para Roma o processo para a confirmação episcopal de Moura. Os documentos chegaram à Santa Sé no dia 29 de junho seguinte, mas quando Luís Moutinho Álvares e Silva, representante do Brasil para os Estados da Igreja, apresentou o pedido do Conselheiro Bento da Silva Lisboa, então Ministro dos Estrangeiros, pedindo a postulação do Pe. Moura, não recebeu a esperada confirmação. A nota a respeito, datada de 14 de setembro de 1833, vinha assinada pelo cardeal Tommaso Bernetti, e alegava que Moura não possuía "as qualidades exigidas nas pessoas eclesiásticas, especialmente naquelas a serem promovidas à dignidade episcopal". Isso, devido a quatro motivos principais: ele estava impedido canonicamente (fora ordenado padre em São Paulo sem as dimissórias do bispo de Mariana, seu prelado de origem); não era dotado de sã doutrina (havia subscrito os três projetos heterodoxos); tinha "defeitos de natal" (era filho bastardo) e "defeitos de corpo" (encontrava-se afetado de paralisia parcial na tenra idade de 39 anos), e era imputado de "outras graves coisas" (entre as quais, a embriaguez, tanto explorada na imprensa da época). ${ }^{7}$ Assim sendo, solicitava-se a Moutinho pedir ao imperador brasileiro que apresentasse outro candidato para que a Igreja do Rio "fosse solicitamente provista de digno pastor". 8

Sem desistir, Luís Moutinho respondeu dois dias depois, tentando minimizar o teor das acusações, mas a Santa Sé rebateu sua posição com outra nota seca, no dia 27 do mesmo mês. A essa altura, a Cúria Romana julgava a pendência liquidada, mas o representante brasileiro ainda voltaria a insistir

6 Silva, J. B. A. (artigo sem título), In: A Arca de Noé (13/4/1833), p. 1-2.

7 ASV, "Cópia confidencial”, In: Nunciatura Apostólica no Brasil, fasc. 13, caixa 3, doc. 39, fl. 91.

8 ASV, "Breve memória histórica", In: Nunciatura Apostólica no Brasil, fasc. 18, caixa 4, doc. 83, fl. $239 \mathrm{~b}$. 
com uma nota oficial no dia 13 de outubro. De novo foi desatendido, e daquela data até dezembro de 1834 nada se fez, cessando inclusive a correspondência. Nesse ínterim, em 21 de fevereiro de 1834, Aureliano Coutinho substituiu Bento Lisboa na pasta dos estrangeiros, e também Moutinho cedeu seu lugar em Roma a José Joaquim da Rocha. O novo representante do Brasil conseguiria do Sumo Pontífice a promessa de concessão da bula, mas com uma condição: que o Pe. Antônio Moura", mesmo sem uma retratação formal, subscrevesse "conveniente declaração", afirmando a sanidade da sua doutrina. ${ }^{10}$

Isso não aconteceria, porque a tendência predominante na política brasileira era aquela de enrijecer em relação à Igreja, como ficou demonstrado durante a aprovação do o Ato Adicional à Constituição, em 12 de agosto de 1834. Esse documento substituiu a Regência Trina pela Regência Una, mas também afetou as estruturas eclesiásticas, agravando ainda mais a situação do clero. Dentre outras disposições, o artigo $10^{\circ} \S 1$ do referido documento deu às Assembleias Provinciais a atribuição de legislar sobre a divisão eclesiástica, e sobre conventos e quaisquer associações religiosas; enquanto que o $§ 7$ estabeleceu que todos os eclesiásticos que recebiam a minguada côngrua das folhas do Tesouro, ficavam oficialmente reduzidos a funcionários públicos. $\mathrm{E}$, para dar o toque final ao férreo cerco que se montava, no dia 7 de abril de 1835 o pleito nacional para o regente único elegeu Pe. Diogo Antônio Feijó, a quem foram dados 2.828 votos, contra 2.251 recebidos pelo seu opositor, o nordestino Francisco de Paula Hollanda Cavalcanti de Albuquerque.

Antes mesmo que Feijó assumisse, o deputado maranhense Estevão Rafael de Carvalho (1800-1846) tomou a iniciativa de "resolver" a problemática da vacância do Rio e de toda a Igreja do Brasil, propondo em 6 de junho de 1835 um cisma unilateral (ANAIS... 1876, p. 154). A proposta caiu por total falta de apoio, mas a eliminação de um cisma imediato não era ainda a solução, pois o Pe. Moura, pressionado pelos homens do Governo, negou-se a fazer qualquer reconsideração, tendo inclusive feito publicar no dia 16 de junho do mesmo ano sua negativa no Correio Oficial.

9 ASV, "Nota verbal do Cardeal Bernetti" (10-9-1835), In: Nunciatura Apostólica no Brasil, fasc. 18 , caixa 4 , doc. 28 , fl. 67.

10 ASV, "Breve memória histórica", In: Nunciatura Apostólica no Brasil, caixa 4, fasc. 18, doc. 83, fl. 245. 
E foi assim que se chegou ao dia 24 de agosto de 1835, data em que Antônio de Meneses Vasconcelos Drumond, novo ministro brasileiro em Roma, em uma conferência que teve com o cardeal Secretário de Estado, declarou-lhe haver recebido resposta à correspondência que mandara em fevereiro para o Rio, que continha instruções para pedir em termos peremptórios a instituição canônica de Moura. No caso do Papa se recusar, informou, devia pedir os passaportes e romper relações diplomáticas com a Santa Sé. Drumonnd ainda não havia recebido o Correio Oficial, e quando teve em mãos a declaração do candidato à vacante diocese carioca, compreendeu que já não havia negociação possível. Assim, enviou uma nota à Cúria no dia 23 de setembro, pediu seus passaportes e declarou que esperaria a resposta em Nápoles até 23 de novembro, dia em que as relações diplomáticas do Brasil com a Santa Sé seriam rompidas de modo cabal, a menos que o Papa houvesse organizado expressamente um consistório para dar a instituição canônica requerida. Se tal não ocorresse, seria oficializada a separação da Igreja do Brasil. ${ }^{11}$

A posse do padre-regente, ocorrida no dia 12 de outubro, parecia ser o último passo para a consumação de um cisma irremediável, inclusive porque ele havia se tornado maçom. Acontecera dois anos antes, quando se iniciara na loja "Amizade", na qual viria a atingir nos anos sucessivos o grau n. 18 (CASTELLANI, [s.d.], p. 4-7). E como Pe. Moura era amigo e colega de ideias do recém-empossado, Feijó, num dos seus arroubos habituais, ameaçou: "Quanto ao Doutor Moura a questão é outra. Faço o máximo empenho na confirmação desse titular da Igreja. E para tal vou até a separação da Igreja brasileira da de Roma".

O regente, no entanto, cometeu o erro fatal de subestimar a reação que provocaria em Roma e no Brasil. Sem se intimidar com as ameaças recebidas, no dia 28 de novembro seguinte a Secretaria de Estado da Santa Sé enviou ao encarregado brasileiro uma resposta duríssima, rebatendo todas as suas objeções. ${ }^{12}$ Entre os brasileiros as reações não foram menos iradas, cabendo de novo a Dom Romualdo Seixas a primazia de, sem perda de tempo, aglutinar em torno de si todas as numerosas inimizades que o regente possuía, entre as

11 ASV, "Breve memória histórica", In: Nunciatura Apostólica no Brasil, caixa 4, fasc. 18, doc. 83, fl. 245.

12 ASV, "Resposta da Secretaria de Estado ao Cavalheiro Drumonnd" (18/11/1835), In: Nunciatura Apostólica no Brasil, fasc. 18, caixa 4, doc. 80, fl. 193 - 203.

Rev. Pistis Prax., Teol. Pastor., Curitiba, v. 2, n. 1, p. 193-210, jan./jun. 2010 
quais os influentes Honório Hermeto e Bernardo Pereira de Vasconcelos. Surpreendido pela reação compacta, Feijó mudou de tática, tentando induzir o legislativo a consolidar o cisma que o executivo não conseguira, na fala do trono proferida em de maio de 1836. Não convenceu, e a oposição parlamentar se tornou cada vez mais poderosa. A questão, aliás, foi resolvida ainda naquele ano, com a derrubada por ampla maioria dos projetos apoiados pelo regente. Afinal, com o prestígio completamente desgastado, em 19 de setembro de 1837 ele renunciou. Em seu lugar assumiu interinamente Pedro Araújo Lima, presidente da Câmara dos deputados, e tido como conciliador. Em abril de 1838 seria eleito regente único. No ano seguinte, no discurso da Coroa, ele anunciou oficialmente o reatamento das relações com a Santa Sé, dando por encerrada a embaraçosa questão da nomeação dos bispos. Nesse meio tempo, através de uma carta datada de $1^{\circ}$ de outubro de 1838 , enviada a Bernardo de Vasconcelos, então ministro da Justiça, Pe. Moura já havia desistido da indicação episcopal e regressado para São Paulo, onde reassumiu a cátedra de que era titular na faculdade local, caindo em seguida no anonimato, no qual faleceu em 12 de março de 1842 (NOGUEIRA; FIRMO, 1973, p. 300).

\section{O ostracismo final de Feijó}

Entrementes, em 10 de julho de 1838 também Feijó fez uma retratação pública, publicada oito dias depois no jornal O Observador Paulistano; mas a sinceridade do seu gesto suscita dúvidas, considerando que quase em seguida assumiu atitudes semelhantes às de outrora. Um exemplo disso foi o projeto que ele, na condição de "senador perpétuo", apresentou no dia 30 de outubro do ano seguinte, solicitando a convocação de um concílio nacional. Esse concílio seria convocado pelo Governo, com o objetivo de realizar "a reforma dos costumes, a extirpação dos abusos, e estabelecer a uniformidade da disciplina em toda a Igreja brasileira, restabelecendo a antiga autoridade do Metropolita, quanto for necessário para este fim". ${ }^{13}$

O desejo de restabelecer "a antiga autoridade do Metropolita" obedecia a uma intenção simples e conhecida: aumentava-se o poder dos bispos, porquanto nacionais, os quais, súditos pelo território, legitimariam o regalismo

13 AAEESS, “Projeto de Concílio nacional” (1839), In: América I (Brasil) fasc. 155, pos. 37, fl. 71. 
civil. Rejeitada a proposta pelos senadores, Feijó não desistiu e, substituindo alguns termos como "concílio nacional" por "concílio provincial", a reapresentou. Bernardo de Vasconcelos estava atento, e se encarregou de refutála ponto por ponto, alegando que o Governo não possuía poder para decidir nessa matéria. A derrota silenciou por algum tempo o "campeão do regalismo" brasileiro, mas, não obstante a idade avançada e os problemas de saúde, em breve ele retornaria à seara política. Sua última proeza de relevo foi a participação na Revolução Liberal de 1842, da qual inclusive se tornou um dos líderes. Derrotados os rebeldes, ele foi preso em Sorocaba e deportado para Vitória, ES. Depois da anistia, continuou atuando no Senado, mas se transformara numa figura secundária no cenário nacional, vindo a morrer no ostracismo em São Paulo, às 11 horas da noite de 10 de novembro de 1843 (TALASSI, 1949, p. 313).

A imprensa deu escassa importância ao fato, mas Feijó ainda contava com alguns admiradores. O Pe. Pedro Gomes de Camargo, nas exéquias celebradas em sua honra na capela do convento de Nossa Senhora do Monte do Carmo, dedicar-lhe-ia uma oração fúnebre repleta de elogios:

Um homem simples, desinteressado, um cidadão tão importante, tão virtuoso. [...] Despido de orgulho e vaidade, levando o seu desinteresse até ao desprezo dos bens caducos da terra; religioso sem superstição ou fanatismo, [...] sua elevação, sua glória, em nada alteraram a bondade de seu coração (CAMARGO, 1843, p. 4-5).

Bem diversa, obviamente, era a versão de Bernardo de Vasconcelos: "O Sr. Feijó é hoje só lembrado apenas como um furacão que deixou ruína, como um terremoto, que abalou o Império, que ele recebeu unido e abandonou lacerado" (ELLIS JÚNIOR, 1940, p. 365). Com ele fazia coro Dom Romualdo Seixas, que nas suas Memórias definiu Feijó como inimigo de sua classe, isso porque "ele procurou despojá-la de sua independência, e nunca se serviu do poder e influência que granjeou, para prestar-lhe o menor auxílio ou favor. [...] Faltou-lhe o amor e espírito do seu espírito sacerdotal" (SEIXAS, 1861, p. 44).

Curiosamente, um último fato ainda marcaria a história do falecido: o destino do seu cadáver. O corpo do padre foi embalsamado, revestido com os paramentos e, em 14 de novembro, transportado para a igreja dos Terciários de 
Nossa Senhora do Carmo. Mas a saga não se concluiu ali. Nove anos depois, o ataúde foi trasladado para a igreja de São Francisco da Penitência, e lá desapareceria até ser reencontrado por funcionários do Instituto Histórico e Geográfico. Após a identificação, os restos mortais foram depositados na cripta da Sé paulistana (CORREA, 1932, p. 211), onde enfim, sob os frios mármores da catedral, repousaram em paz.

\section{REFERÊNCIAS}

\section{Fontes arquivísticas}

\section{AAEESS: Affari Ecclesiastici Straordinari - Vaticano}

- América I (Brasil) fasc. 155, pos. 37.

ASV: Archivio Segreto del Vaticano - Nunziatura Apostolica in Brasile

- Fasc. 10, caixa 3: Governo imperial

- Fasc. 13: Secretaria de Estado e outros dicastérios (nomeação de Moura)

- Fasc. 18, caixa 4: sobre a nomeação episcopal do cônego Antônio Maria de Moura.

ANAIS DO PARLAMENTO BRASILEIRO. CÂMARA DOS DEPUTADOS, 5., 1827, Rio de Janeiro. Sessão... Rio de Janeiro: Tipografia de Hipólito José Pinto e Cia, 1876.

BRASIL. Constituição política do Império do Brasil (1824). Seguida do Ato Adicional (1834). Rio de Janeiro: Eduardo Henrique e Laemmert Editores, 1863.

BURTON, R. Viagem do Rio de Janeiro a Morro Velho. Itatiaia: Belo Horizonte, 1976.

CAMARGO, P. G. Oração fúnebre por ocasião das exéquias feitas de corpo presente ao Ex.mo e Rev.mo Sr. Diogo Antônio Feijó, grã cruz da imperial ordem do cruzeiro e senador do Império, na igreja do convento de Nossa Senhora do Monte do Carmo da imperial cidade de São Paulo, aos 15 de novembro de 1843. São Paulo: Tipografia do Governo arrendada por Silva Cabral, 1843. 
CASTELLANI, J. Os maçons que fizeram a história no Brasil. São Paulo: A Gazeta Maçônica, [19--?].

CORRÊA, V. Gaveta de sapateiro. São Paulo: Companhia Editora Nacional, 1932.

GURGEL, M. J. A. Análise da resposta do Ex.mo Arcebispo da Bahia sobre a questão da dispensa do celibato, pedida pelo Conselho Geral de São Paulo. Rio de Janeiro: Tipografia Ambrosiana, 1834.

KIDDER, D. P. Reminiscências de viagens e permanências no Brasil. São Paulo: Livraria Martins, 1972.

ELLIS JÚNIOR, A. Feijó e sua época. São Paulo: Universidade de São Paulo, 1940.

NOGUEIRA, O.; FIRMO, J. S. Parlamentares do Império. Brasília: Centro Gráfico do Senado Federal, 1973.

ORICO, O. O demônio da regência. São Paulo: Companhia Editora Nacional, 1930.

PIRES, H. Temas de história eclesiástica do Brasil. São Paulo: São Paulo Editora, 1946.

RUBERT, A. A Igreja no Brasil. Santa Maria: Livraria Editora Palloti, 1993. v. 4.

SARAIVA, J. H. História concisa de Portugal. Mira-Sintra: Publicações EuropaAmérica, 1993.

SEIXAS, R. A. Memórias do Marquês de Santa Cruz. Rio de Janeiro: Tipografia Nacional, 1861.

SILVA, J. B. A. A Arca de Noé (13/4/1833).

SOUZA, O. T. Diogo Antônio Feijó. Belo Horizonte: Itatiaia, 1988.

TALASSI, L. A doutrina do Padre Feijó e suas relações com a Sé Apostólica. Roma: Pontifícia Universidade Gregoriana, 1949

Recebido:16/10/2009

Received: 10/16/2009

Aprovado: 30/10/2009

Approved: 10/30/2009 